\title{
Differences in MUC4 Expression in Pancreatic Cancers and Pancreatic Cysts in Egypt
}

Asserewou Etekpo ${ }^{1}$, Ahmad Alghawalby ${ }^{2}$, Marwa Alghawalby ${ }^{2}$, Amr S Soliman ${ }^{3}$, Ahmed Hablas ${ }^{4}$, Baojiang Chen ${ }^{5}$, Surinder Batra ${ }^{6}$ and Ghada A Soliman $^{7,8 *}$

${ }^{1}$ Department of Epidemiology, College of Public Health, University of Nebraska Medical Center, Omaha Nebraska, USA

${ }^{2}$ Department of Radiotherapy, Faculty of Medicine, Mansoura University, Mansoura, Egypt

${ }^{3}$ Department of Community Health and Social Medicine, School of Medicine, City University of New York, New York, USA

${ }^{4}$ The Gharbiah Cancer Society, Tanta, Egypt

${ }^{5}$ Department of Biostatistics, College of Public Health, University of Nebraska Medical Center, Omaha, Nebraska, USA

${ }^{6}$ Department of Biochemistry and Molecular Biology, College of Medicine, University of Nebraska Medical Center, Omaha Nebraska, USA

${ }^{7}$ Department of Environmental, Occupational and Geospatial Health Sciences, Graduate School of Public Health and Health Policy, City University of New York, New York, USA

${ }^{8}$ Advanced Science Research Center, City University of New York, New York, USA

*Corresponding author: Ghada A. Soliman, Department of Environmental, Occupational and Geospatial Health Sciences, Graduate School of Public Health and Health Policy, City University of New York, USA, Tel:(646) 364-9515; E-mail: ghada.soliman@sph.cuny.edu

Received date: March 01, 2018; Accepted date: March 19, 2018; Published date: March 26, 2018

Copyright: 2018 Etekpo, et al. This is an open-access article distributed under the terms of the Creative Commons Attribution License, which permits unrestricted use, distribution, and reproduction in any medium, provided the original author and source are credited.

\begin{abstract}
Pancreatic cancer is the fourth cause of cancer deaths in the U.S. with most patients diagnosed at advanced stages followed by short survival. Therefore, biomarkers for early detection are urgently needed. Mucin 4 (MUC4) is a mucin protein encoded by the MUC4 gene and identified in the majority of pancreatic cancers. With increasing clinical identification and diagnosis of pancreatic cysts globally and transformation of some cysts into pancreatic cancer, it is important to evaluate if MUC4 is expressed in pancreatic cysts.
\end{abstract}

Immunohistochemistry assays utilizing heat-induced epitope retrieval (HIER) were performed to examine MUC4 protein expression in 44 paraffin-embedded tissues of pancreatic cancers and 20 pancreatic cysts. All patients were diagnosed and operated upon at the Mansoura University Gastrointestinal Surgery Center in Egypt. Clinical, demographic, and survival information were abstracted from the patients' medical records. Logistic regression was performed to predict expression of MUC4 protein in cancer and cysts, by type of cysts.

Pancreatic cyst patients were significantly younger than pancreatic cancer patients (Mean age of $28.7 \pm 5.25$ vs. $54.84 \pm 10.60$ years) $(p=0.0001)$. Expression of MUC4 was not different between cancers and pancreatic cysts $(p=0.16)$. However, type of pancreatic cysts was predictive of MUC4 expression. Mucinous cystic neoplasms and serous cystadenoma cysts showed significantly higher MUC4 expression than non-specified and pseudocysts $(80 \%$, $75 \%, 25 \%$, and $0 \%$ expression for the 4 types of cysts, respectively) $(p=0.022)$.

MUC4 expression may be associated with certain types of cysts. Follow-up of pancreatic cyst patients who show MUC4 expression might reveal clues to early detection of pancreatic cancer.

Keywords: Pancreatic cancer; pancreatic cysts; MUC4; Egypt

\section{Introduction}

Pancreatic Cancer is one of the short-survival cancers with one-year relative survival rate of approximately $29 \%$, and the five-year rate of about $7 \%$ in the U.S. $[1,2]$. Pancreatic cancer is the $19^{\text {th }}$ most common cancer in Africa [3] and is not one of the common cancers in Egypt. However, the disease is diagnosed at advanced disease stages [4] and is characterized by high mortality [5]. Pancreatic cancer in Egypt also occurs at a relatively young age of diagnosis [6] and is more common in polluted regions [7], and shows variation in mutations by place of residence in relation to pollution levels in the country $[8,9]$.

Mucins are high molecular weight glycoproteins that play a protective function for the epithelial cells under normal physiological conditions. Mucins are also involved in the renewal and differentiation of epithelial tissue and modulation of cell adhesion and cell signaling [10]. Mucins have been associated with various types of cancers based on the alteration in their expression. MUC4 is membrane-bound mucin that is overexpressed in pancreatic cancer but absent in normal pancreas and chronic pancreatitis [11].

Recent studies have shown MUC4 expression in $91 \%$ of tissues of pancreatic cancer patients [12] and increased expression with advancing stages of pancreatic cancer and poor patient survival [13], but $M U C 4$ is not expressed in normal pancreas [14]. This finding may imply that mucins play a critical role in pancreatic cancer development. The manifestations of these mucins in pancreatic tumor cells indicate that MUC4 can be potential biomarker for pancreatic cancer diagnosis and possibly early detection.

Due to absence of early stage tissues and serum samples from pancreatic cancer patients, early detection remains a challenge. 
Therefore, identifying pre-cancerous lesions and biomarker genes involved in the development of pancreatic cancer could be very relevant to early detection.

Pancreatic cysts are lesions of the pancreas that have been identified more frequently in the U.S. and increasingly so in other countries because of improved diagnostic imaging facilities of Magnetic Resonance Imaging (MRI) and Computed Tomography (CT) [15]. The prevalence of pancreatic cysts from different imaging studies of asymptomatic patients ranged between $1-20 \%[1,2,6,7,16]$ and different histopathologic types of cysts are identified [15]. A proportion of those cysts have potentials for malignant transformation and new molecular assays might be helpful for differential diagnosis and assessment of early detection of malignant transformation of pancreatic cysts [17].

Therefore, we conducted this study to compare and contrast MUC4 expression in pancreatic cancer and pancreatic cysts from Egyptian patients diagnosed and treated at the Mansoura University Gastrointestinal Surgery Center. The study also aimed at exploring the relationship between MUC4 expression pattern and patients' demographic, occupational, lifestyle factors.

\section{Material and Methods}

\section{Study site and patient population}

The Gastrointestinal Surgery Center (GSC) is a surgical center of the Mansoura University located in Mansoura city, the $4^{\text {th }}$ largest city in Egypt in the East Nile Delta region. The vast majority of patients who are referred to the center reside in the Dakahleya province. The province is the home of approximately 5.9 million individuals who live in the space area of $3470.0 \mathrm{~km}^{2}$ [18]. Faculty of the center perform a full range of diagnostic and management gastrointestinal procedures. Approximately, $40 \%$ of the patients are treated free-of-charge, $40 \%$ by the national health insurance, and $20 \%$ of patients pay the treatment expenses out-of-pocket.

This case-case study included 44 pancreatic cancer and 20 pancreatic cyst patients diagnosed and treated at the GSC. The pancreatic cancer patients were diagnosed and confirmed as ductal adenocarcinoma of the pancreas and were included in our previous publications $[8,9]$. The 2 groups of patients represented consecutive patients managed at the GSC and all tissues had histopathologic confirmation from paraffin-embedded tissue blocks prepared from the resected lesions. The pancreatic cancer represented $26 \%$ of all incident pancreatic cancer patients seen at the GSC hospital during the period of 1998-2004. The rest of the patients, who were diagnosed during the same period but not included in this study, had medical or palliative treatment and no surgical resections or biopsies were performed on them. The pancreatic cyst patients were diagnosed and underwent resection at GSC during a period of 2002 to 2015. Histopathologic confirmation of pancreatic cancer and pancreatic cysts were confirmed by pathologists from the GSC in Egypt and 2 pathologists in the U.S. [M.D. Anderson Cancer Center (SRH) and University of Nebraska Medical Center (AL)]. Demographic, clinical, and risk factor information was obtained from the pancreatic cancer patients by interviewing from our previous study [9], and the clinical and risk factor information was abstracted from the medical records of the pancreatic cyst patients. The information included age, occupation (agricultural, professional and technical or administrative), residence (urban versus rural), smoking and family history of cancer. The study was approved by the IRB committees of the University of Nebraska Medical Center and the GSC in Egypt.

\section{Immunohistochemistry analysis of $M U C 4$}

Section of the paraffin-embedded tissues blocks of the pancreatic cancer patients and the pancreatic cysts were tested for MUC4 by immunohistochemistry utilizing heat-induced epitope retrieval (HIER) as described [13]. The slides were baked at 58 degrees overnight in the oven. The next day, the slides were deparaffinized by washing 3 times (10 min each) in xylene solution. The tissues were rehydrated with decreasing concentrations of 200 proof ethanol $(100 \%$, $90 \%, 80 \% 70 \% 50 \%$ and $30 \%$ ) then washed with running water for 5 $\min$. The tissues were incubated for $30 \mathrm{~min}$ in $3 \%$ hydrogen peroxidase $\left(\mathrm{H}_{2} \mathrm{O}_{2}\right)$ in methanol to block the endogenous peroxidase. Afterwards, the tissues were blocked in 2.5\% horse serum (Cat \#: MP-750) from VECTOR for $1 \mathrm{~h}$. Without washing the tissue section, primary antibody MUC4 (8G7) Cat \#: SC 53945 from Santa Cruz was added at the dilution of 1:1000 and was incubated overnight. Normal colon mucosa was used as positive control specimen for MUC4. For the negative control, pancreatic cancer tissues and pancreatic cyst tissue were used for immunohistochemistry staining and 1X PBS substituted the primary antibody. The tissues were then washed 3 times for 5 minutes, each with $1 \mathrm{X}$ PBST to remove the background. The second antibody Mouse/Rabbit I g Cat\# MP-7500 R.TU/Normal horse serum from Vector was added enough to cover the slides. The tissues were incubated at room temperature for $1 \mathrm{~h}$. Detection was performed using DAB kit following the manufacturer's instructions (cat\# SK -4100. Vector, Inc.), followed by hematoxylin staining. The slides were washed for $10 \mathrm{~min}$ under running water. The tissues were dehydrated with increasing ethanol concentration $(70 \%, 80 \%, 90 \%$, and $100 \%)$ for 5 min, each followed by 5 minutes of xylene wash. The slides were dried for 15-30 min and the permanent mounting solution was added and covered with glass.

\section{Data management and statistical analysis}

A student's t test was performed to compare means and standard deviations of continuous variables of the 2 patient groups. These variables were: age and intensity of staining. Fisher exact test was performed to determine the difference in proportions between the 2 patient groups for the following variables: sex, smoking status, rural/ urban residence, family history of cancer, and occupation. Two logistic regression models were performed to predict MUC4 expression. The first model was performed to predict expression of MUC4 in pancreatic cancer versus pancreatic cysts controlling for age, sex, and smoking status. The second model was performed to predict MUC4 expression based on the type of cysts, controlling for the same variables of the first logistic regression model. The type of cysts was coded as follows: Type 0 (pseudo cyst and not otherwise specified) and Type 1 (mucinous cystic neoplasms and serous cystadenomas). The intensity of MUC4 expression was grouped in 2 ways. First, staining was scored from 0 to 3, and 0 intensity was coded as "no expression" while any staining from 0.5 to 3 was coded as "expression". Second, different codes were given based on the degree of staining as follow: $0.5=$ "very low", 1="low", 1.5="less moderate", 2="moderate", 2.5="high", and $3=$ "very high" and analyzed as a continuous variable based on the numerical scores. P-value of less than 0.05 was considered statistically significant. All statistical analyses were conducted using SAS 9.3 (SAS, Cary, NC, USA). 
Citation: Etekpo A, Alghawalby A, Alghawalby M, Soliman AS, Hablas A, et al. (2018) Differences in MUC4 Expression in Pancreatic Cancers and Pancreatic Cysts in Egypt. J Carcinog Mutagen 9: 312. doi:10.4172/2157-2518.1000312

Page 3 of 6

\section{Results}

Comparison of the demographic characteristics of the 2 study groups are presented in Table 1 . The descriptive statistical analysis showed that pancreatic cyst patients were younger (Mean age of $28.7 \pm$ 5.25 y) compared to pancreatic cancer patients (Mean age $54.84 \pm$ $10.60 \mathrm{y})(\mathrm{p}=0.0001)$. A statistically significant high proportion of men $(56.82 \%)$ were among the pancreatic cancer group compared to the cyst group (10.00\%) while females represented $43.1 \%$ and $90.0 \%$, of the pancreatic cancer and cyst groups, respectively $(\mathrm{p}=0.0004)$. There was a significant difference between the pancreatic cancer patients and the cyst patients with respect to smoking status. None of the cyst patients were smokers while $54.6 \%$ of cancer patients were smokers $(\mathrm{p}=0.001)$. In term of residence, $59.9 \%$ of pancreatic cancer patients lived in rural area while $80 \%$ of the pancreatic cyst patients lived in rural areas $(\mathrm{p}=0.2615)$. Pancreatic cancer patients were more employed in farming than pancreatic patients, $36.59 \%$ and $20 \%$, for the 2 groups, respectively $(\mathrm{p}=0.1892)$. None of the patients from the 2 groups reported having family history of pancreatic cancer.

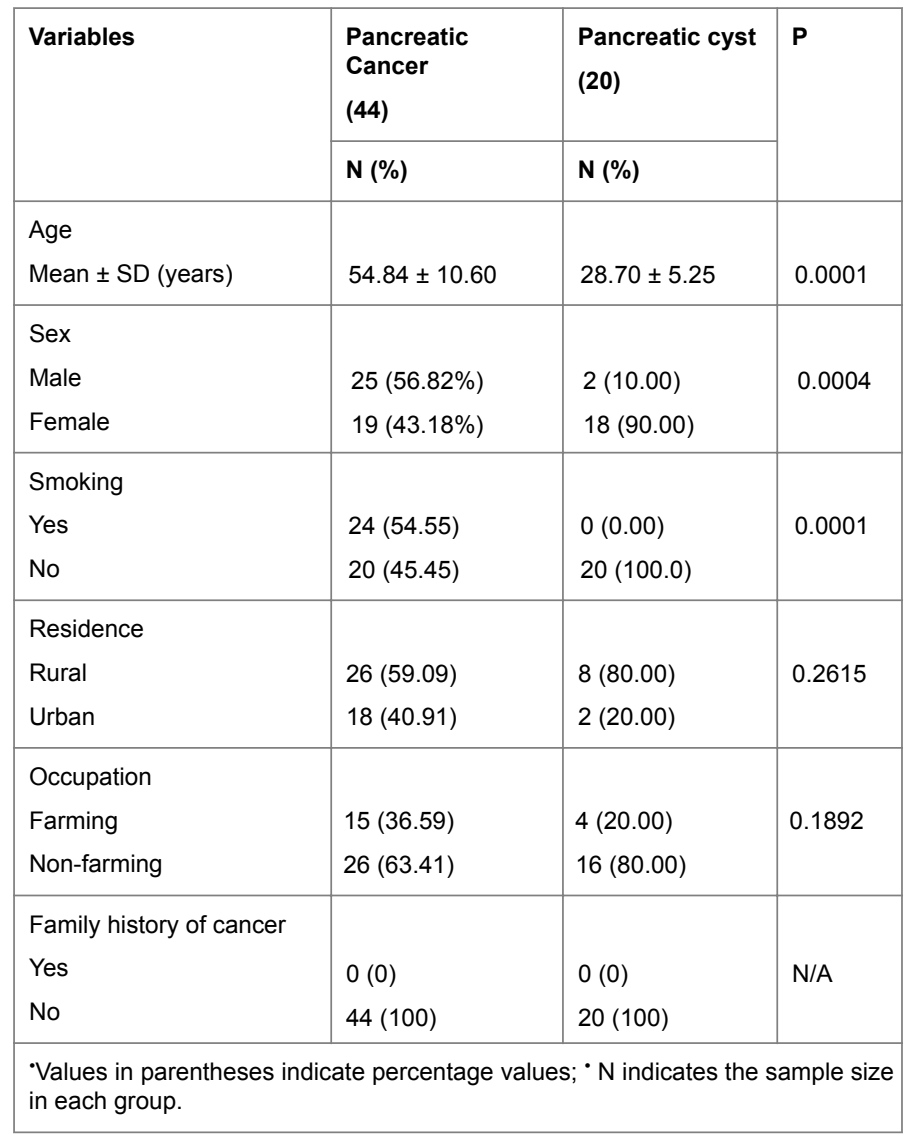

Table 1: Demographic and Epidemiologic Characteristics of the Study Population.

MUC4 protein expression was detected using immunohistochemistry. Normal colon mucosa was used as positive control. Pancreatic cancer tissues without primary antibody added was used a negative control. Tables $2 \mathrm{a}$ and $2 \mathrm{~b}$ show the intensity of expression of MUC4 by type of cysts. Eighty percent of the mucinous cystic neoplasms stained positive and showed an aberrant expression of MUC4 protein. MUC4 expression was observed as well at moderate and less intense staining in $75 \%$ of serous cystadenomas. In contrast, only $25 \%$ of "not otherwise specified cysts" (NOS) showed low expression of MUC4 and none of the pseudo cysts expressed MUC4, suggesting that MUC4 expression is up-regulated in mucinous cystic neoplasms and serous cystadenomas. MUC4 expression was not detected in the pseudo cysts. Age and sex did not show significant relationship to the level of MUC4 expression.

\begin{tabular}{|c|c|c|c|c|c|c|}
\hline \multirow[t]{2}{*}{ Intensity } & \multicolumn{5}{|c|}{ Type of Cyst } & \multirow[b]{2}{*}{$P$} \\
\hline & $\begin{array}{l}\text { Mucinous } \\
\text { cystic } \\
\text { neoplas } \\
\text { ms } \\
(\mathrm{N}=10)\end{array}$ & $\begin{array}{l}\text { Serous } \\
\text { cystadenoma } \\
(\mathrm{N}=4)\end{array}$ & $\begin{array}{l}\text { Pseudo } \\
\text { cyst } \\
(\mathrm{N}=2)\end{array}$ & $\begin{array}{l}\text { Not } \\
\text { Otherwise } \\
\text { Specified } \\
(\mathrm{N}=4)\end{array}$ & Total & \\
\hline \multirow{2}{*}{ yes } & 8 & 3 & 0 & 1 & 12 & \multirow[t]{4}{*}{0.0057} \\
\hline & $80 \%$ & $75 \%$ & $0 \%$ & $25 \%$ & & \\
\hline \multirow{2}{*}{ no } & 2 & 1 & 2 & 3 & 8 & \\
\hline & $20 \%$ & $25 \%$ & $100 \%$ & $75 \%$ & & \\
\hline
\end{tabular}

Table 2a: MUC4 Protein Expression in Type of Cysts.

\begin{tabular}{|c|c|c|c|c|c|}
\hline \multicolumn{4}{|c|}{ Clinical Data } & \multicolumn{2}{|c|}{ Expression Level } \\
\hline Sample & Age & Sex & $\begin{array}{l}\text { Type of } \\
\text { Cyst }\end{array}$ & MUC4 & $\begin{array}{l}\text { Percentage of Cells } \\
\text { staining }\end{array}$ \\
\hline 1 & 25 & $\mathrm{~F}$ & $\mathrm{MCN}$ & ++++ & $80 \%$ \\
\hline 2 & 21 & $\mathrm{~F}$ & SCA & + & Less than $40 \%$ \\
\hline 3 & 27 & M & SCA & ++ & $50 \%$ \\
\hline 4 & 24 & $\mathrm{~F}$ & $\mathrm{MCN}$ & +++++ & $50-70 \%$ \\
\hline 5 & 37 & M & NOS & - & $0 \%$ \\
\hline 6 & 30 & $\mathrm{~F}$ & SCA & +++++ & $90 \%$ \\
\hline 7 & 28 & $\mathrm{~F}$ & SCA & - & Less than $10 \%$ \\
\hline 8 & 24 & $\mathrm{~F}$ & PS & - & $0 \%$ \\
\hline 9 & 35 & $\mathrm{~F}$ & $\mathrm{MCN}$ & - & $0 \%$ \\
\hline 10 & 20 & $\mathrm{~F}$ & $\mathrm{MCN}$ & + & Less than $10 \%$ \\
\hline 11 & 22 & $\mathrm{~F}$ & $\mathrm{MCN}$ & +++++ & $50-60 \%$ \\
\hline 12 & 27 & $\mathrm{~F}$ & $\mathrm{MCN}$ & ++++ & $60-80 \%$ \\
\hline 13 & 35 & $\mathrm{~F}$ & NOS & - & $0 \%$ \\
\hline 14 & 30 & $\mathrm{~F}$ & $\mathrm{MCN}$ & ++ & $60-70 \%$ \\
\hline 15 & 24 & $\mathrm{~F}$ & NOS & - & $0 \%$ \\
\hline 16 & 32 & $\mathrm{~F}$ & NOS & + & $20 \%$ \\
\hline 17 & 31 & $\mathrm{~F}$ & $\mathrm{MCN}$ & +++++ & $80 \%$ \\
\hline 18 & 32 & $\mathrm{~F}$ & $\mathrm{MCN}$ & - & $10 \%$ \\
\hline 19 & 35 & $\mathrm{~F}$ & PS & - & $0 \%$ \\
\hline 20 & 35 & $\mathrm{~F}$ & $\mathrm{MCN}$ & +++++ & $90 \%$ \\
\hline
\end{tabular}


Page 4 of 6

MCN=Mucinous cystic neoplasm; SCA=Serous cystic Adenoma; $\mathrm{PS}=$ Pseudocyst; NOS=Not otherwise specified. No Stain $(-)$ +Low level $(+)$; Moderate(++); Very moderate(+++); High(++++); Very high(+++++).

Table 2b: MUC4 Protein Expression in Pancreatic Cysts by Immunohistochemistry.

Tables $3 \mathrm{a}$ and $3 \mathrm{~b}$ present the results of the logistic regression models. Table 3a shows that MUC4 expression was not predictive of the type of the lesion (pancreatic cancers versus cysts) $(\mathrm{p}=0.106)$. After controlling for age, sex, and smoking status, MUC4 remained unpredictable of the type of lesion (pancreatic cancer and pancreatic cyst) $(\mathrm{p}=0.733)$.

The second logistic regression model analysis was performed to predict MUC4 protein expression based on the type of pancreatic cyst (Table 3a). The result showed that mucinous cystic neoplasms and serous cystadenoma cysts, combined, were 18 times more likely to express MUC4 protein than the pseudo cyst and the not otherwise specified cysts $(\mathrm{p}=0.022)$. After controlling for age and sex, the prediction was 16 times in comparing the 2 respective groups $(\mathrm{p}=0.041)$. We did not control for smoking status because none of the cyst patients were smokers.

We analyzed the difference between pancreatic cancer and pancreatic cyst in term of intensity (Table 3c). In the first analysis, we considered intensity as a continuous variable and found that pancreatic cancer tissues stained more but with non-statistically significant difference between pancreatic cancers $(1.44 \pm 0.92)$ and pancreatic cysts $(1.27 \pm 1.30)$, respectively $(\mathrm{p}=0.5561)$. The results of the categorical analysis showed that $80 \%$ of pancreatic cancers tissues had some staining compared to $60 \%$ of pancreatic cysts ( $\mathrm{p}=0.1008$ ).

Table 3a: Logistic regression analysis to predict MUC4 protein expression in pancreatic cysts and pancreatic cancer

\begin{tabular}{|c|c|c|}
\hline & OR $(95 \% \mathrm{Cl})$ & $\mathbf{p}$ \\
\hline \multicolumn{2}{|c|}{ Unadjusted Model } & \\
\hline Cysts & 1 & \\
\hline Cancer & $03.8(0.12-1.22)$ & 0.1063 \\
\hline \multicolumn{2}{|c|}{ Adjusted Model } & \\
\hline Cysts & 1 & \\
\hline Cancer & $0.70(0.09-5.37)$ & 0.7332 \\
\hline \multicolumn{3}{|l|}{ Sex } \\
\hline Female & 1 & \\
\hline Male & $0.82(0.17-3.84)$ & 0.807 \\
\hline \multicolumn{3}{|c|}{ Smoking } \\
\hline Yes & 1 & \\
\hline No & $0.90(0.17-4.78)$ & 0.909 \\
\hline Age & $0.97(0.90-1.01)$ & 0.408 \\
\hline
\end{tabular}

Table 3b: Logistic regression to predict MUC4 protein based on type of pancreatic cyst

OR $(95 \% \mathrm{Cl})$

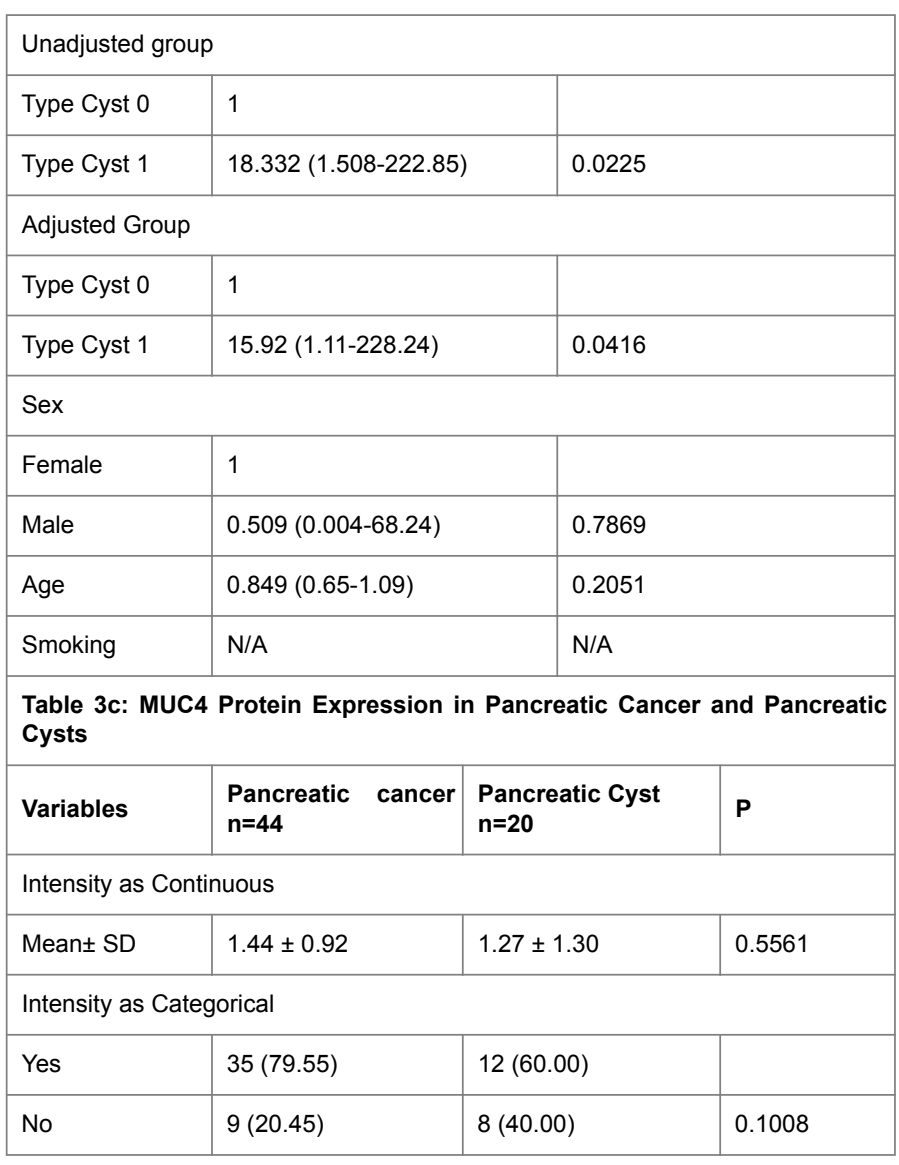

Table 3: Logistic regression analysis to predict $M U C 4$ protein expression in pancreatic cysts and pancreatic cancer, to predict MUC4 protein based on type of pancreatic cyst, and the protein expression in pancreatic cancer and pancreatic cysts.

\section{Discussion}

Our study revealed the following interesting observations. First, the results showed high level of MUC4 expression in both pancreatic cancer and pancreatic cyst tissues, with no significant difference in the level of expression between the two groups. We also found that higher expression of MUC4 was not predictive of pancreatic cancer or cyst status. Second, the study revealed higher expression of MUC4 in mucinous cystic neoplasms and serous cystadenoma cysts than the expression in pseudo cysts and the not otherwise specified cysts. Mucinous cystic neoplasms and serous cystadenoma cysts were predictive of higher expression of MUC4.

The results of this study confirmed findings from previous studies that showed MUC4 expression in intraductal papillary mucinous neoplasm (IPMN) of the pancreas [19] and pancreatic cancer [20,21] with increased MUC4 expression in advanced stage of the disease [13]. Chronic pancreatitis could impose higher risk for pancreatic cancer but studies that compared MUC4 expression in pancreatic cancer and chronic pancreatitis showed MUC4 expression in 91\% of pancreatic cancer but not in chronic pancreatitis tissues [11]. Mucins belong to a family of large O-glycoproteins that serve protection function for epithelial cells against various injuries such as inflammation, bacteria, and viruses under normal physiological conditions [22]. During pancreatic carcinogenesis, gradual expression of MUC4 has been 
demonstrated by immunohistochemistry in pancreatic intra-epithelial lesions (PanIN) in the rate of $17 \%$ of PanIN1A, 36\% of PanIN2, and $85 \%$ of PanIN3 [22]. In pancreatic ductal adenocarcinoma, the prevalence of MUC4 expression reached 83 to $89 \%$ of tumors [22].

Some pancreatic cysts have potentials to transform into invasive pancreatic cancer [23-25]. Cyst fluids have been used to diagnose the malignancy of cysts by cytological examination, tumor markers, and cyst fluid viscosity [25]. Tumor marker carcinoembryonic antigen (CEA) has the highest diagnostic accuracy of $79 \%$ (sensitivity of $73 \%$, specificity of $84 \%$ ) for discriminating premalignant mucinous cysts from non-mucinous cysts [26]. Also, MUC5AC expression was detected in mucinous but not in other types of cysts [26]. No previous studies have investigated MUC4 expression in pancreatic cysts and our study is the first investigation of this possible association.

Pancreatic cancer remains as one of the most severe types of cancer with poor prognosis and lack of efficient biomarkers for early detection. The mortality rate from pancreatic cancer almost matches its incidence $[27,28]$ and the disease is always diagnosed at advanced stages, where treatment is no longer effective. The absence of specific biomarkers for early detection explains the late diagnosis. Identifying pre-cancerous lesions and genes involved in the development of pancreatic cancer could be crucial for early detection. Several studies have revealed expression of different $M U C$ genes in the development of pancreatic carcinogenesis and the pattern of their expression at different stages of tumor progression [13,28-34].

The strengths of this study include the access to a relatively large number of clinically and histologically well-characterized patients from large gastrointestinal surgery center in Egypt, the histopathologic confirmation of the pancreatic cancer and cyst tissues in both Egypt and the U.S., and the availability of clinical and survival information of patients. A limitation of the study could be the hospital-based nature of the study and the limited generalization of the results to other populations in Egypt.

\section{Summary}

This study showed a statistically significant association between some types of cysts (Mucinous cystic neoplasms and serous cystadenoma cysts) and MUC4 expression. About $60 \%$ of the pancreatic cysts expressed MUC4 protein. This suggests that these patients could be at risk for developing pancreatic cancer and may need to be monitored. There are currently no diagnostic indicators that are consistently reliable, obtainable, and conclusive for diagnosing and risk-stratifying pancreatic cysts. Future studies should focus on setting- up a follow-up cohort study of patients with pancreatic cysts in this population. The follow-up of a cohort could provide clues to early detection of pancreatic cancer and better understanding of the risk of pancreatic cancer for pancreatic cyst patients.

\section{Funding Support}

Asserewou Etekpo was supported by the Cancer Epidemiology Education in Special Populations (CEESP) Program of the University of Nebraska (Grant R25 CA112383).

\section{Acknowledgement}

We would like to thank Dr. Stanley R. Hamilton at the University of Texas M.D. Anderson Cancer Center for reviewing the histopathological diagnosis of pancreatic cancer tissues.
We would also like to thank Dr. Audrey Lazenby at the University of Nebraska Medical Center for reviewing the histopathology of pancreatic cysts and scoring the immune-hisotochemical staining of the slides.

\section{References}

1. American Cancer Society (2016) Cancer Facts \& Figures 2016. American Cancer Society, Georgia.

2. Howlader N, Noone AM, Miller D, Bishop K, Alterkruse SF, et al. (2015) SEER Cancer Statistics Review, 1975-2013. National Cancer Institute, Bethesda.

3. Boyle P, Levin B (2008) Internation Agency for Research and Cancer, elibrary. World Cancer Report, IARC Press, Lyon.

4. Ibrahim AS, Ismail K, Hablas A, Hussein H, Elhamzawy H, et al. (2007) Cancer in Egypt, Gharbial: Triennial Report of 2000-2002. Gharbiah Population Based Cancer Registry.

5. Soliman AS, Zhang Q, Saleh T, Zarzour A, Selim M, et al. (2006) Pancreatic cancer mortality in Egypt: comparison to the United States pancreatic cancer mortality rates. Cancer Detect Prev 30: 473-479.

6. Soliman AS, El Ghawalby N, Ezzat F, Bondy ML, Soultan A, et al.(2002) Unusually high rate of young onset pancreatic cancer in the East Nile Delta region of Egypt. Int J Gastrointest Cancer 32: 143-151.

7. Kriegel AM, Soliman AS, Zhang Q, El Ghawalby N, Ezzat F, et al. (2006) Serum cadmium levels in pancreatic cancer patients from the East Nile Delta region of Egypt. Environmental health perspectives 114: 113-119.

8. Soliman AS, Bondy M, Webb CR, Schottenfeld D, Bonner J, et al. (2006) Differing molecular pathology of pancreatic adenocarcinoma in Egyptian and United States patients. Int J Cancer 119: 1455-1461.

9. Soliman AS, Lo AC, Banerjee M, El Ghawalby N, Khaled HM, B et al. (2007) Differences in K-ras and p53 gene mutations among pancreatic adenocarcinomas associated with regional environmental pollution. Carcinogenesis J 28: 1794-1799.

10. Moniaux N, Escande F, Porchet N, Aubert JP, Batra SK (2001) Structural organization and classification of the human mucin genes. Front Biosci 6: D1192-1206.

11. Andrianifahanana M, Moniaux N, Schmied BM, Ringel J, Friess H, et al. (2001) Mucin (MUC) gene expression in human pancreatic adenocarcinoma and chronic pancreatitis: a potential role of MUC4 as a tumor marker of diagnostic significance. Clin Cancer Res 7: 4033-4040.

12. Jhala N, Jhala D, Vickers SM, Eltoum I, Batra SK, et al. (2006) Biomarkers in Diagnosis of pancreatic carcinoma in fine-needle aspirates. Am J Clin Pathol 126: 572-579.

13. Swartz MJ, Batra SK, Varshney GC, Hollingsworth MA, Yeo CJ, et al. (2002) MUC4 expression increases progressively in pancreatic intraepithelial neoplasia. Am J Clin Pathol 117: 791-796.

14. Rachagani S, Torres MP, Kumar S, Haridas D, Baine M, et al. (2012) Mucin (Muc) expression during pancreatic cancer progression in spontaneous mouse model: potential implications for diagnosis and therapy. J Hematol Oncol 5: 68.

15. De Jong K, Bruno MJ, Fockens P (2012) Epidemiology, diagnosis, and management of cystic lesions of the pancreas. Gastroenterol Res Pract 147465.

16. Mortada WI, Sobh MA, el Defrawy MM, Farahat SE (2002) Reference intervals of cadmium, lead, and mercury in blood, urine, hair, and nails among residents in Mansoura city, Nile delta, Egypt. Environ Res 90: 104-110.

17. Ke E, Patel BB, Liu T, Li XM, Haluszka O, et al. (2009) Proteomic analyses of pancreatic cyst fluids. Pancreas 38: e33-42.

18. Central Agency for Public Mobilisation and Statistics (2013) Arab Republic of Egypt, "Egypt in figures: Population Estimates by Governorate (Urban/rural areas)," 2011. J Saf Sci Tech 3: 2013.

19. Kitazono I, Higashi M, Kitamoto S, Yokoyama S, Horinouchi M, et al. (2013) Expression of MUC4 mucin is observed mainly in the intestinal 
Citation: Etekpo A, Alghawalby A, Alghawalby M, Soliman AS, Hablas A, et al. (2018) Differences in MUC4 Expression in Pancreatic Cancers and Pancreatic Cysts in Egypt. J Carcinog Mutagen 9: 312. doi:10.4172/2157-2518.1000312

Page 6 of 6

type of intraductal papillary mucinous neoplasm of the pancreas Pancreas 42: 1120-1128.

20. Balague C, Audie JP, Porchet N, Real FX (1995) In situ hybridization shows distinct patterns of mucin gene expression in normal, benign, and malignant pancreas tissues. Gastroenterology 109: 953-964.

21. Hollingsworth MA, Strawhecker JM, Caffrey TC, Mack DR (1994) Expression of MUC1, MUC2, MUC3 and MUC4 mucin mRNAs in human pancreatic and intestinal tumor cell lines. Int J Can 57: 198-203.

22. Jonckheere N, Skrypek N, Van Seuningen I (2010) Mucins and pancreatic cancer. Cancers 2: 1794-1812.

23. Matthaei H, Schulick RD, Hruban RH, Maitra A (2011) Cystic precursors to invasive pancreatic cancer. Nat Rev Gastroenterol Hepatol 8: 141-150.

24. Jana T, Shroff J, Bhutani MS (2015) Pancreatic cystic neoplasms: Review of current knowledge, diagnostic challenges, and management options. J Carcinog 14: 3 .

25. Al Haddad M (2015) Role of emerging molecular markers in pancreatic cyst fluid. Endosc Ultrasound 4: 276-283.

26. Park WG (2011) Screening for pancreatic cancer: what can cyst fluid analysis tell us?. F1000 Med Rep 3: 3.

27. Yip Schneider MT, Wu H, Dumas RP, Hancock BA, Agaram N, et al (2014) Vascular endothelial growth factor, a novel and highly accurate pancreatic fluid biomarker for serous pancreatic cysts. J Am Coll Surg 218: 608-617.
28. Schmidt CM (2013) Pancreatic cyst cytology: optimization of cancer risk profiling. Cancer Cytopathol 121:2-3.

29. Saitou M, Goto M, Horinouchi M, Tamada S, Nagata K, et al. (2005) MUC4 expression is a novel prognostic factor in patients with invasive ductal carcinoma of the pancreas. J Clin Pathol 58: 845-852.

30. Takikita M, Altekruse S, Lynch CF, Goodman MT, Hernandez BY, et al. (2009) Associations between selected biomarkers and prognosis in a population-based pancreatic cancer tissue microarray. Cancer Res 69: 2950-2955.

31. Yamasaki H, Ikeda S, Okajima M, Miura Y, Asahara T, et al. (2004) Expression and localization of MUC1, MUC2, MUC5AC and small intestinal mucin antigen in pancreatic tumors. Int J Oncol 24: 107-113.

32. Moniaux N, Junker WM, Singh AP, Jones AM, Batra SK (2006) Characterization of human mucin MUC17. Complete coding sequence and organization. J Biol.Chem 281: 23676-23685.

33. Haridas D, Chakraborty S, Ponnusamy MP, Lakshmanan I, Rachagani S, et al. (2011) Pathobiological implications of MUC16 expression in pancreatic cancer. PloS one 6: e26839.

34. Chauhan SC, Ebeling MC, Maher DM, Koch MD, Watanabe A, et al. (2012) MUC13 mucin augments pancreatic tumorigenesis. Mol Cancer ther 11:24-33. 